Bangladesh Rice J. 20 (1) : 23-32, 2016

\title{
Postharvest Loss Assessment of Rice at Selected Areas of Gazipur District
}

\author{
B C Nath*, M A Hossen, A K M S Islam, M D Huda, S Paul, M A Rahman
}

\begin{abstract}
Mechanical intervention in rice (Oryza sativa L.) postharvest operation especially harvesting, threshing and carrying is increasing due to shifting labour from agriculture to non-agricultural sector. It was hypothesized that mechanical intervention in rice postharvest operation will increase the postharvest losses. A two-year study (2008-2010) was conducted during Aus, Aman and Boro seasons in six locations of sadar upazila at Gazipur district to test the hypothesis. The widely used varieties of BR11, BR23, BR26, BR27, BRRI dhan28, BRRI dhan29 were used to assess the losses during harvesting to drying. In the study areas, farmer's common practices (harvesting paddy by sickle; transportation by head, shoulder and power tiller operated trolley; threshing by open drum and close drum thresher; cleaning by traditional cleaning device kula and winnower and sun drying) were used to assess the postharvest losses. The average postharvest losses from harvesting to drying recorded $10 \%$ in three rice growing seasons. Losses due to mechanical threshing and traditional sun drying were $3.16 \%$ and $3.14 \%$ respectively. Power tiller operated trolley showed the lowest carrying loss compared to shoulder and head carrying methods. Both kula and winnower were observed as the most appropriate method of grain cleaning. Mechanical intervention in threshing increased the losses, whereas decreased in transportation and winnowing. These data might be used for policy makers to assess the national food grain loss and for researchers to design and development new technology to reduce the postharvest loss. The study should be continued to other regions for consistent results.
\end{abstract}

Key words: Mechanical intervention, harvesting, carrying, threshing, drying

\section{INTRODUCTION}

Bangladesh produced 34.4 million tons of clean rice in 10.61 million hectares land (BRRI, 2014). Two millions of population added in each year and expected to reach 215.4 million in 2050 when 44.6 million ton of cleaned rice will be required (Kabir et al., 2016) whereas the estimated annual shrinkage of agricultural land is about 0.08 million hectares due to various non-agricultural activities such as the construction of houses, offices, roads, mills, factories etc (BRRI, 2009). Rice yield, therefore, needs to be increased from its present level of 2.74 to $3.74 \mathrm{t} \mathrm{ha}^{-1}$ (BRRI, 2013). Decreasing resources (e.g. land, labour, soil health and water) and increasing climate vulnerability (e.g. drought, salinity, flood, heat and cold) appeared as the great challenges to keep pace of food production in the background of increasing population. Sufficient rice production is the key to ensure food security in Bangladesh. In fact, 'rice security' is synonymous to 'food security' in Bangladesh as in many other rice growing countries (Brolley, 2015).

The government has given the top priority in increasing the availability of food in the country, while rice land is not expanding (MoA, 2013). One way to increase the production is to minimize yield gap between research and farmers level. Another important task is to minimize postharvest loss. Rice postharvest practices in the country vary between localities depending upon the existing physical, topographical and climatic conditions in the area.

Farm Machinery and Postharvest Technology Division, BRRI, Gazipur, Bangladesh. *Corresponding author's E-mail: bidhanbrri@gmail.com 
A portion of the rice (paddy) is lost in postharvest operations due to numerous factors and a portion of rice is wasted to feed poultry and livestock, and in transportation, marketing and consumption processing. The wastes indicate that postharvest food loss translates not just into human hunger and minimizing the revenue of farmers, but tremendous environmental waste as well (Afsar et al., 2001). It was also varied with seasons, variety and mode of operations.

FAO/BRRI (1986) estimated postharvest losses (harvest to storage) in Bangladesh were 13.02-13.72\% (drying loss: 1.63\%-2.84\%, parboiling loss: $1.93-2.75 \%$ and milling loss: $3.28 \%$ and $4.54 \%$ ) in three rice growing seasons. Little variation of total losses was observed in different seasons (Aman-13.04, Boro-13.02 and Aus-13.75\%). Mechanical intervention in post harvest operation was not included in that study. After 1998, the wide scale adoption of power tiller for tilling caused tremendous changes in the crop production sector. Land preparation, irrigation, weeding and threshing are already mechanized successfully in Bangladesh although some operations like transplanting, harvesting, winnowing, drying are still gaining space in farmers' level (Islam et al., 2016). There is insufficient data on postharvest losses of rice in Bangladesh after introducing machinery in rice cultivation. It is urgently needed to estimate the losses occurred due to mechanical intervention in postharvest operation. Therefore, the aim of this study is to assess the postharvest losses (harvesting to drying) in rice for providing information to reduce postharvest losses.

\section{MATERIALS AND METHODS}

\section{Experiment site, variety and rice growing seasons}

Considering easy access from BRRI headquarters and to secure farmers' cooperation, six blocks of Gazipur sadar upazila in Gazipur district were selected to assess the post harvest losses of rice in 20082010 seasons. Table 1 presents detailed information of seasons and varieties in six locations.

\section{Experimental design}

The experiment was laid out in randomized complete block design. Six postharvest operations were considered (harvestingsickle; transportation- head, shoulder and power tiller operated trolley; threshing- open drum and close drum thresher; cleaningtraditional cleaning device kula and winnower and drying-sun) in this study. The method(s) in each operation were replicated three times. Existing farmers' practices were taken in consideration to determine the postharvest losses including selection of crops maturity date; harvesting process, threshing methods and drying practices in each stage.

\section{Experimental procedure}

The method and procedures in this study were followed as mentioned by Jose et al., (1985). Table 2 describes field techniques and laboratory procedure for determination of postharvest losses of rice.

\section{Laboratory techniques}

The grain samples and raw data were collected from the field and analyzed in the research laboratory, FMPHT division, BRRI. The collected samples were cleaned, weighed and recorded the moisture content. Filled and unfilled grains were counted manually and weights were adjusted to $14 \%$ moisture content (wet basis).

\section{Procedures}

According to Jose et al. (1985), the sample of $50 \mathrm{~m}^{2}$ area was harvested by sickle; stacking on canvas; bundled by rope; transported by head/shoulder/trolley; threshed by ODT/ CDT to get the grain weight as yield. The loss was calculated on the basis of grain weight expressed as average and percentage. Pre-testing was done before the final test in order to minimize the error in each methods and seasons. 
Table 1. Information on experimental location, season and variety.

\begin{tabular}{lcccccc}
\hline Season & \multicolumn{2}{c}{ Aus } & \multicolumn{2}{c}{ Aman } & \multicolumn{2}{c}{ Boro } \\
\cline { 2 - 7 } Location & Laxmipur & Chandana & Mariali & Harinal & Purba Chandana & Jogitala \\
\hline Year & 2008 & 2009 & 2008 & 2009 & 2009 & 2010 \\
Variety & BR26 & BR27 & BR23 & BR11 & BRRI dhan28 & BRRI dhan29 \\
\hline
\end{tabular}

Table 2. Field operation techniques and components at different stages of crop production.

\begin{tabular}{|c|c|c|c|}
\hline Operation & Loss component & Tool & Collected datum \\
\hline $\begin{array}{l}\text { Reaping } \\
\text { a. Pre-harvest }\end{array}$ & $\begin{array}{l}\text { Shattering loss due to environmental } \\
\text { condition(wind, rain) }\end{array}$ & - & Amount of paddy fallen \\
\hline b. Harvest & harvesting & Sickle & Amount of paddy fallen \\
\hline $\begin{array}{l}\text { Field stacking/ } \\
\text { bundling }\end{array}$ & Staking/bundling loss & - & Amount of paddy fallen \\
\hline Field transport & $\begin{array}{l}\text { During the process of transporting } \\
\text { the harvested grain }\end{array}$ & $\begin{array}{l}\text { Head/shoulder } \\
\text { and trolley }\end{array}$ & Amount of paddy fallen \\
\hline Threshing & Scattered and un-threshed & ODT and CDT & $\begin{array}{l}\text { Amount of scattered, un- } \\
\text { separated and un-threshed } \\
\text { paddy }\end{array}$ \\
\hline $\begin{array}{l}\text { Cleaning/ } \\
\text { winnowing }\end{array}$ & Scattered, chaff and straw loss & $\begin{array}{l}\text { Winnower and } \\
\text { kula }\end{array}$ & $\begin{array}{l}\text { Amount of scattered and } \\
\text { un-separated (chaff and } \\
\text { straw) paddy }\end{array}$ \\
\hline Drying & $\begin{array}{l}\text { Quantity loss (birds, chicken, duck, } \\
\text { spoilage, yard etc.) }\end{array}$ & Sun drying & $\begin{array}{l}\text { Quantity loss (amount } \\
\text { paddy loss by weight) }\end{array}$ \\
\hline
\end{tabular}

ODT= Open drum thresher; CDT=Close drum thresher

\section{Postharvest operations}

Determination of harvesting losses. The field was marked with nylon rope and bamboo pole for harvesting. One-twentieth portion $\left(2.5 \mathrm{~m}^{2}: 0.5 \times 5 \mathrm{~m}\right)$ of the total area $\left(50 \mathrm{~m}^{2}\right)$ in one end was used for measuring the preharvesting (natural shattering loss by wind, varietal characteristics) and harvesting (cutting) loss of manual harvesting by sickle. The remaining $47.5 \mathrm{~m}^{2}$ area was also harvested by sickle to determine the grain yield. Grain falls on the ground was collected manually for calculating pre and post harvesting losses.

Determination of in-field stacking/ bundling losses. Leave the harvested paddy on the canvas, as in the normal practice of the farmer and allowing the farmer to carry the harvested paddy by bundling for threshing. Grains falls on the canvas during bundling was collected in a poly bag for laboratory analysis.
Determination of transport losses. Power tiller operated trolley, head and shoulder carrying methods as common practiced in the study area for transport the harvested paddy to the threshing floor. Clothing bag were added for head and shoulder carrying and lay out the plastic sheet on the trolley to collect the fallen grain during transportation.

Determination of threshing losses. Two different types of threshing methods (ODT, CDT) as practiced by farmers were used to determine the threshing losses. Plastic sheet was laid down on the threshing floor for collecting scattered paddy from outside of the threshing range. Weighted all the threshed straw and taken $1 / 16^{\text {th }}$ of that straw (Jose et al., 1985), which is called straw factor, used to determination of un-threshed paddy.

Determination of winnowing/cleaning losses. Two types of equipment (winnower and kula) were used for the purpose of cleaning losses. Initially, weight of threshed 
paddy (un-cleaned) were recorded and cleaned by winnower and kula. Finally, the weight of cleaned paddy was measured to estimate the cleaning loss. Scattered paddy was collected from outside the winnowing range and gathered chaff to collect paddy.

Determination of drying losses. Sun drying method was used for the purpose of drying loss calculation. Weighted the cleaned paddy and dried in the famers' yard and finally again weighted the dried paddy for drying loss calculation.

\section{Procedure of loss calculation}

The following formulas were used to calculate postharvest losses of rice.

Moisture conversion factor (MCF): $\frac{100-\mathrm{M}_{1}}{86}$

Where,

$$
\mathrm{M}_{1}=\text { Initial moisture }
$$

Area faction (AF): $\frac{50 m^{2}}{2.5 m^{2}}=20$

Straw factor (SF): $\frac{\text { Totalstraw }}{16}$

Rice yield (RY): $\mathrm{Y}_{2}=\mathrm{Y}_{1} \times \mathrm{MCF} \times \mathrm{F}_{\mathrm{g}}$

Where,

$$
\begin{aligned}
& \mathrm{Y}_{1}= \text { Weight of the grain of the sample } \\
& \text { area at field moisture content } \\
& \text { including filled and unfilled grain } \\
& \\
&(\mathrm{kg}) \\
& \mathrm{F}_{\mathrm{g}}=\text { Percentage }(\%) \text { of the filled } \\
& \text { grains } \\
& \mathrm{Y}_{2}=\text { Adjusted weight of the grain of } \\
& \text { the sample area at } 14 \% \text { moisture } \\
& \text { content }(\mathrm{kg})
\end{aligned}
$$

Preharvest loss: $\mathrm{P}_{\mathrm{r} 2}=\mathrm{P}_{\mathrm{r} 1} \times \mathrm{MCF} \times \mathrm{AF}$ and

$$
\mathrm{P}_{\mathrm{r} 3}=\frac{\mathrm{P}_{\mathrm{r} 2}}{\mathrm{Y}_{2}} \times \frac{1}{10}
$$

Where,

$\mathrm{P}_{\mathrm{r} 1}=$ Preharvest loss of rice $\left(2.5 \mathrm{~m}^{2}\right)$ at field moisture content $(\mathrm{g})$
$\mathrm{P}_{\mathrm{r} 2}=$ Preharvest loss of rice $\left(50 \mathrm{~m}^{2}\right)$ at $14 \%$ moisture content $(\mathrm{kg})$

$\mathrm{P}_{\mathrm{r} 3}=$ Preharvest loss in \%

Postharvest loss: $\mathrm{P}_{\mathrm{o} 2}=\mathrm{P}_{\mathrm{o} 1} \times \mathrm{MCF} \times \mathrm{AF}$ and

$\mathrm{P}_{\mathrm{o} 3}=\frac{\mathrm{P}_{\mathrm{o} 2}}{\mathrm{Y}_{2}} \times \frac{1}{10}$

Where,

$\mathrm{P}_{\mathrm{o} 1=\text { Postharvest loss of rice }\left(2.5 \mathrm{~m}^{2}\right) \text { at }}$

field moisture content $(\mathrm{g})$

$\mathrm{P}_{\mathrm{o} 2}=$ Postharvest loss of rice $\left(50 \mathrm{~m}^{2}\right)$ at $14 \%$ moisture content $(\mathrm{kg})$

$\mathrm{P}_{\mathrm{o} 3}=$ Postharvest loss in \%

Field bundling/stacking loss: $\mathrm{F}_{\mathrm{b} 2}=\mathrm{F}_{\mathrm{b} 1} \times \mathrm{MCF}$

and $F_{b 3}=\frac{F_{b 2}}{Y_{2}} \times \frac{1}{10}$

Where,

$\mathrm{F}_{\mathrm{b} 1}=$ Stacking / bundling loss of rice (2.5

$\mathrm{m}^{2}$ ) at field moisture content (g)

$\mathrm{F}_{\mathrm{b} 2}=$ Field stacking loss of rice $\left(50 \mathrm{~m}^{2}\right)$ at

$14 \%$ moisture content $(\mathrm{kg})$

$\mathrm{F}_{\mathrm{b} 3=}=$ Field staking/ bundling loss in $\%$

Transport loss: $\mathrm{T}_{2}=\mathrm{T}_{1} \times \mathrm{MCF}$ and

$$
\mathrm{T}_{3}=\frac{\mathrm{T}_{2}}{\mathrm{Y}_{2}} \times \frac{1}{10}
$$

Where,

$\mathrm{T}_{1}=$ Transport loss of rice $\left(2.5 \mathrm{~m}^{2}\right)$ at field moisture content $(\mathrm{g})$

$\mathrm{T}_{2}=$ Transport loss of rice $\left(50 \mathrm{~m}^{2}\right)$ at $14 \%$

moisture content $(\mathrm{kg}){ }_{3}=$ Transport loss in \%

\section{Threshing loss}

Scattering loss: $\mathrm{T}_{\mathrm{sc} 2}=\mathrm{T}_{\mathrm{sc} 1} \times \mathrm{MCF}$ and

$$
\mathrm{T}_{\mathrm{sc} 3}=\frac{\mathrm{T}_{\mathrm{sc} 2}}{\mathrm{Y}_{2}} \times \frac{1}{10}
$$

Where,

$\mathrm{T}_{\mathrm{hc1}}=$ Scattering loss of rice $\left(2.5 \mathrm{~m}^{2}\right)$ at field moisture content $(\mathrm{g})$

$\mathrm{T}_{\mathrm{hc} 2}=$ Scattering loss of rice $\left(50 \mathrm{~m}^{2}\right)$ at $14 \%$ moisture content $(\mathrm{kg})$

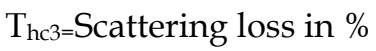


Separation loss: $\mathrm{T}_{\mathrm{se} 2}=\mathrm{T}_{\mathrm{se} 1} \times \mathrm{MCF} \times \mathrm{SF} \times \mathrm{F}_{\mathrm{g}}$ and

$$
\mathrm{T}_{\mathrm{se} 3}=\frac{\mathrm{T}_{\mathrm{se} 2}}{\mathrm{Y}_{2}} \times \frac{1}{10}
$$

Where,

$\mathrm{T}_{\text {he1 }}=$ Separation loss of rice $\left(2.5 \mathrm{~m}^{2}\right)$ at field moisture content (g)

$\mathrm{T}_{\text {he2 }}=$ Separation loss of rice $\left(50 \mathrm{~m}^{2}\right)$ at $14 \%$ moisture content $(\mathrm{kg})$

$\mathrm{T}_{\text {he3 }}=$ Separation loss in $\%$

Total threshing loss (\%): $\mathrm{T}_{\mathrm{sc} 3}+\mathrm{T}_{\mathrm{se} 3}$

\section{Clearing/winnowing loss}

Scattering loss: $\mathrm{C}_{\mathrm{sc} 2}=\mathrm{C}_{\mathrm{sc} 1} \times \mathrm{MCF}$ and

$$
\mathrm{C}_{\mathrm{sc} 3}=\frac{\mathrm{C}_{\mathrm{sc} 2}}{\mathrm{Y}_{2}} \times \frac{1}{10}
$$

Where,

$\mathrm{C}_{\mathrm{sc} 1}=$ Scattering loss of rice $\left(2.5 \mathrm{~m}^{2}\right)$ at field moisture content $(\mathrm{g})$

$\mathrm{C}_{\mathrm{sc} 2}=$ Scattering loss of rice $\left(50 \mathrm{~m}^{2}\right)$ at $14 \%$ moisture content $(\mathrm{kg})$

$\mathrm{C}_{\mathrm{sc} 3}=$ Scattering loss in $\%$

Chaff and straw separation loss: $C_{\mathrm{se} 2}=$

$$
\mathrm{C}_{\mathrm{se} 1} \times \mathrm{MFC} \times \mathrm{F}_{\mathrm{g}} \text { and } \mathrm{C}_{\mathrm{se} 3}=\frac{\mathrm{C}_{\mathrm{se} 2}}{\mathrm{Y}_{2}} \times \frac{1}{10}
$$

Where,

$\mathrm{C}_{\mathrm{se} 1}=$ Chaff and straw loss of rice $\left(2.5 \mathrm{~m}^{2}\right)$ at field moisture content $(\mathrm{g})$

$\mathrm{C}_{\mathrm{se} 2}=$ Chaff and straw loss of rice $\left(50 \mathrm{~m}^{2}\right)$ at $14 \%$ moisture content $(\mathrm{kg})$

$\mathrm{C}_{\mathrm{se} 3}=$ Chaff and straw loss in $\%$

'Total cleaning/winnowing loss (\%):

$\mathrm{C}_{\mathrm{hc} 3}+\mathrm{C}_{\mathrm{se} 3}$
Drying loss: $\mathrm{D}_{2 \mathrm{i}}=\mathrm{D}_{1 \mathrm{i}} \times \mathrm{MCF} \times \mathrm{F}_{\mathrm{g}}$ and $\mathrm{D}_{2 \mathrm{f}}=\mathrm{D}_{1 \mathrm{f}}$ $\times \mathrm{MCF} \times \mathrm{F}_{\mathrm{g}}$

$$
\text { Drying Loss, }(\%)=\frac{\left(D_{2 i}-D_{2 f}\right)}{D_{2 i}} \times 100
$$

Where,

$\mathrm{D}_{1 \mathrm{i}}=$ Initial weight at field moisture content $(\mathrm{kg})$

$\mathrm{D}_{2 \mathrm{i}}=$ Adjusted weight at $14 \%$ moisture content $(\mathrm{kg})=\mathrm{Y}_{2}$

$\mathrm{D}_{1 \mathrm{f}}=$ Weight of the sample after drying $(\mathrm{kg})$

$\mathrm{D}_{2 \mathrm{f}}=$ Adjusted weight after drying at $14 \%$ moisture content $(\mathrm{kg})$

\section{Statistical analysis}

Data were analyzed according to Gomez and Gomez (1984) using statistical software Statistix 10 programme. Means were compared with least significant difference (LSD) test.

\section{RESULTS AND DISCUSSION}

Comparative loss assessment (operation basis) pre-harvest and harvest (cutting) losses. Table 3 shows that the pre-harvest and harvest losses were depended on variety and season. The cutting losses (\%) also varied as same as pre-harvest losses. The harvest loss was the highest in Aus season in both the years due to heavy rainfall and lodging by wind. In contrast, the harvesting loss was observed as the lowest in BRRI dhan28 in Boro season. FAO/BRRI (1986) obtained harvest losses of 2.01, 2.5 and 1.14\% in Aus, Aman and Boro seasons respectively, which is similar to the present findings. 
Table 3. Effect of variety on pre-harvest and harvest (cutting) losses (\%).

\begin{tabular}{|c|c|c|c|c|c|c|}
\hline \multirow{2}{*}{ Item } & \multicolumn{2}{|c|}{ Aus } & \multicolumn{2}{|c|}{ Aman } & \multicolumn{2}{|c|}{ Boro } \\
\hline & BR26 & BRRI dhan27 & BR23 & BR11 & BRRI dhan28 & BRRI dhan29 \\
\hline Pre-harvest loss & 0.53 & 0.74 & 0.20 & 0.33 & 0.36 & 0.37 \\
\hline Harvest loss (Sickle) & 2.10 & 2.15 & 1.88 & 2.00 & 1.83 & 1.94 \\
\hline
\end{tabular}

Transportation losses. Table 4 shows the transportation losses of rice in three seasons. Transportation loss varied significantly with the different methods of carrying except rice variety BR26. Irrespective of seasons, carrying method of power tiller operated trolley reduced the carrying losses significantly whereas losses are at par between head and shoulder carrying methods. FAO/BRRI (1986) observed that transport loss varied 0.52 to $0.57 \%$ for head and shoulder carrying, which is similar to the present findings (Table 4). However, transportation loss obtained the lowest while carrying in power tiller operated trolley. Some grains are separated from the panicle due to vibration and farmers can easily collect those grains from the trolley. Therefore, mechanical intervention reduced the transportation losses.

Threshing losses. Scattered and unthreshed losses are expressed as threshing loss. Two-way interaction of threshing methods and type of threshing losses did not varied significantly whereas single effect of threshing methods and type of losses varied significantly in all seasons (Table 5). Irrespective of season, un-threshed losses showed the highest in CDT (2.48 to $2.69 \%$ ) whereas scattered losses showed the lowest in ODT $(0.56$ to $1.0 \%)$. CDT showed significantly higher grain losses (1.20 to $2.27 \%$ ) in all seasons than ODT (0.86 to $1.21 \%)$. In contrary, un-threshed losses (1.85-2.14\%) were observed significantly higher in all seasons than scattered loss (0.88-1.39\%).FAO/BRRI (1986) obtained threshing loss of $0.81,0.77$ and $0.98 \%$ in Aus, Aman and Boro seasons, respectively in traditional method of threshing. The threshing losses in the present study were higher because of existence of un-threshed grain in the panicle and some grains spillsfar with straw due to high speed throwing of straw.

Table 4. Effect of carrying methods on transportation losses (\%).

\begin{tabular}{|c|c|c|c|c|c|c|}
\hline \multirow{2}{*}{ Carrying method } & \multicolumn{2}{|c|}{ Aus } & \multicolumn{2}{|c|}{ Aman } & \multicolumn{2}{|c|}{ Boro } \\
\hline & BR26 & BRRI dhan27 & BR23 & BR11 & BRRI dhan28 & BRRI dhan29 \\
\hline Trolley & 0.20 & 0.195 & 0.16 & 0.23 & 0.15 & 0.24 \\
\hline Head carry & 0.65 & 0.84 & 0.49 & 0.66 & 0.51 & 0.81 \\
\hline Shoulder carry & 0.75 & 0.79 & 0.69 & 0.63 & 0.72 & 0.72 \\
\hline $\mathrm{LSD}_{0.05}$ & NS & 0.41 & 0.26 & 0.30 & 0.37 & 0.04 \\
\hline CV (\%) & 18.82 & 15.82 & 13.48 & 14.1 & 18.96 & 1.38 \\
\hline
\end{tabular}

NS=Not significant 
Table 5. Effect of threshing method on threshing losses (\%).

Aus

\begin{tabular}{|c|c|c|c|c|c|c|}
\hline \multirow{2}{*}{ Operation } & \multicolumn{3}{|c|}{ BR26 } & \multicolumn{3}{|c|}{ BRRI dhan 27} \\
\hline & Scattered & Un-threshed & Mean & Scattered & Un-threshed & Mean \\
\hline ODT & 0.62 & 1.79 & 1.21 & 0.56 & 1.65 & 1.10 \\
\hline CDT & 1.47 & 2.48 & 1.98 & 1.19 & 2.6 & 1.2 \\
\hline Mean & 1.05 & 2.14 & - & 0.88 & 2.13 & - \\
\hline $\mathrm{LSD}_{0.05}$ & \multicolumn{3}{|c|}{$\mathrm{T}=0.19$ and $\mathrm{M}=0.21, \mathrm{~T} \times \mathrm{M}=\mathrm{NS}$} & \multicolumn{3}{|c|}{$\mathrm{T}=0.29$ and $\mathrm{M}=0.18, \mathrm{~T} \times \mathrm{M}=\mathrm{NS}$} \\
\hline CV $(\%)$ & \multicolumn{3}{|c|}{8.5} & \multicolumn{3}{|c|}{9.3} \\
\hline
\end{tabular}

\begin{tabular}{|c|c|c|c|c|c|c|}
\hline \multirow{3}{*}{ Operation } & \multicolumn{6}{|c|}{ Aman } \\
\hline & \multicolumn{3}{|c|}{ BR23 } & \multicolumn{3}{|c|}{ BR11 } \\
\hline & Scattered & Un-threshed & Mean & Scattered & Un-threshed & Mean \\
\hline ODT & 0.82 & 1.31 & 1.07 & 0.59 & 1.13 & 0.86 \\
\hline CDT & 1.86 & 2.69 & 2.27 & 1.88 & 2.64 & 2.26 \\
\hline Mean & 1.34 & 2.0 & - & 1.24 & 1.89 & - \\
\hline $\mathrm{LSD}_{0.05}$ & \multicolumn{3}{|c|}{$\mathrm{T}=0.41$ and $\mathrm{M}=0.52, \mathrm{~T} \times \mathrm{M}=\mathrm{NS}$} & \multicolumn{3}{|c|}{$\mathrm{T}=0.20$ and $\mathrm{M}=0.20, \mathrm{~T} \times \mathrm{M}=\mathrm{NS}$} \\
\hline $\mathrm{CV}(\%)$ & \multicolumn{3}{|c|}{17.56} & \multicolumn{3}{|c|}{9.09} \\
\hline \multicolumn{7}{|c|}{ Boro } \\
\hline \multirow{2}{*}{ Operation } & \multicolumn{3}{|c|}{ BRRI dhan28 } & \multicolumn{3}{|c|}{ BRRI dhan29 } \\
\hline & Scattered & Un-threshed & Mean & Scattered & Un-threshed & Mean \\
\hline ODT & 1.00 & 1.19 & 1.10 & 0.75 & 1.51 & 1.13 \\
\hline CDT & 1.77 & 2.5 & 2.14 & 1.38 & 2.54 & 1.96 \\
\hline Mean & 1.39 & 1.85 & - & 1.10 & 2.02 & - \\
\hline $\mathrm{LSD}_{0.05}$ & \multicolumn{3}{|c|}{$\mathrm{T}=0.31$ and $\mathrm{M}=0.50, \mathrm{~T} \times \mathrm{M}=\mathrm{NS}$} & \multicolumn{3}{|c|}{$\mathrm{T}=0.55$ and $\mathrm{M}=0.55, \mathrm{~T} \times \mathrm{M}=\mathrm{NS}$} \\
\hline $\mathrm{CV}(\%)$ & \multicolumn{3}{|c|}{9.09} & \multicolumn{3}{|c|}{25.28} \\
\hline
\end{tabular}

$\mathrm{T}=$ Threshing loss type (Scattered and Un-threshed), M=Method of operation (ODT and CDT), NS=Not significant

Cleaning losses. Scattered and chaff losses were considered cumulatively as cleaning losses. Two-way interaction of cleaning methods and type of cleaning losses did not varied significantly whereas single effect of cleaning methods were found significant only in BR26 during Aus season. In contrary, cleaning methods showed significant variation in BR27 and BRRI dhan28 during Aus and Boro season, respectively (Table 6). Cleaning losses in three seasons and two methods of operation (winnower and kula) showed similar in all the seasons. The cleaning loss in-terms of chaff and scattered values have no relation. It was changed regarding season and operation. Irrespective of season, cleaning losses varied from 0.16 to $0.29 \%$ and 0.17 to $0.25 \%$ for winnower and kula and 0.15 to $0.23 \%$ and 0.19 to $0.29 \%$ for scattered and chaff respectively, which is similar to the finding of FAO/BRRI (1986). 
Table 6. Effect of winnowing method on cleaning losses.

\begin{tabular}{|c|c|c|c|c|c|c|}
\hline \multirow{3}{*}{ Operation } & \multicolumn{5}{|c|}{ Aus } & \\
\hline & \multicolumn{3}{|c|}{ BR26 } & \multicolumn{3}{|c|}{ BRRI dhan 27} \\
\hline & Scattered & Chaff & Mean & Scattered & Chaff & Mean \\
\hline Kula & 0.23 & 0.28 & 0.25 & 0.18 & 0.16 & 0.17 \\
\hline Winnower & 0.19 & 0.30 & 0.25 & 0.24 & 0.29 & 0.26 \\
\hline Mean & 0.21 & 0.29 & - & 0.21 & 0.23 & \\
\hline $\mathrm{LSD}_{0.05}$ & \multicolumn{3}{|c|}{$C=0.05$} & \multicolumn{3}{|c|}{$M=0.06$} \\
\hline $\mathrm{CV}(\%)$ & \multicolumn{3}{|c|}{15.04} & \multicolumn{3}{|c|}{20.64} \\
\hline \multicolumn{7}{|c|}{ Aman } \\
\hline & \multicolumn{3}{|c|}{ BR23 } & \multicolumn{3}{|c|}{ BR11 } \\
\hline & Scattered & Chaff & Mean & Scattered & Chaff & Mean \\
\hline Kula & 0.18 & 0.25 & 0.22 & 0.17 & 0.25 & 0.21 \\
\hline Winnower & 0.21 & 0.27 & 0.24 & 0.28 & 0.29 & 0.29 \\
\hline Mean & 0.19 & 0.26 & - & 0.23 & 0.27 & \\
\hline CV (\%) & \multicolumn{3}{|c|}{23.07} & \multicolumn{3}{|c|}{36.85} \\
\hline \multirow{3}{*}{ Operation } & \multirow{2}{*}{\multicolumn{3}{|c|}{$\begin{array}{lr} & \text { Boro } \\
\text { BRRI dhan28 }\end{array}$}} & & & \\
\hline & & & & \multicolumn{3}{|c|}{ BRRI dhan29 } \\
\hline & Scattered & Chaff & Mean & Scattered & Chaff & Mean \\
\hline Kula & 0.18 & 0.17 & 0.17 & 0.19 & 0.17 & 0.18 \\
\hline Winnower & 0.23 & 0.33 & 0.28 & 0.11 & 0.20 & 0.16 \\
\hline Mean & 0.20 & 0.24 & & 0.15 & 0.19 & \\
\hline $\mathrm{LSD}_{0.05}$ & \multicolumn{3}{|c|}{$M=0.07$} & \multicolumn{3}{|c|}{ NS } \\
\hline CV (\%) & \multicolumn{3}{|c|}{21.75} & \multicolumn{3}{|c|}{38.36} \\
\hline
\end{tabular}

$\mathrm{M}=$ Operation, $\mathrm{C}=$ Cleaning loss type (Scattered and chaff), NS=Not significant

Drying losses. Drying losses varied significantly with the seasons (Fig. 1). The average loss estimate in drying operations was ranged from 2.38 to $2.98 \%$ for the three seasons (Aus, Aman and Boro). Significantly higher drying losses were observed in Boro (3.14\%) due to bulk volume of production compared to others seasons, whereas the lowest drying loss (2.68\%) was observed in Aman season, because of dry weather. However, the drying losses were the second highest in Aus season due to rainy days. Greeley(1981) stated that total physical losses in the operation from harvesting to sun drying did not exceed $7 \%$, whereas total drying losses ranged from 1.56 to $5 \%$ (Bala, et al., 2010). Drying loss depends on diversity factor like farmers' initiatives, weather condition and yard condition etc. The possible causes of drying losses were observed that grains feeding by the chicken, birds, ducks, grain spoilage, scattered during drying etc. Drying yard (Mud ground, pacca floor, canvas, bamboo mat, plastic sheet, and road side) also influenced the drying losses.

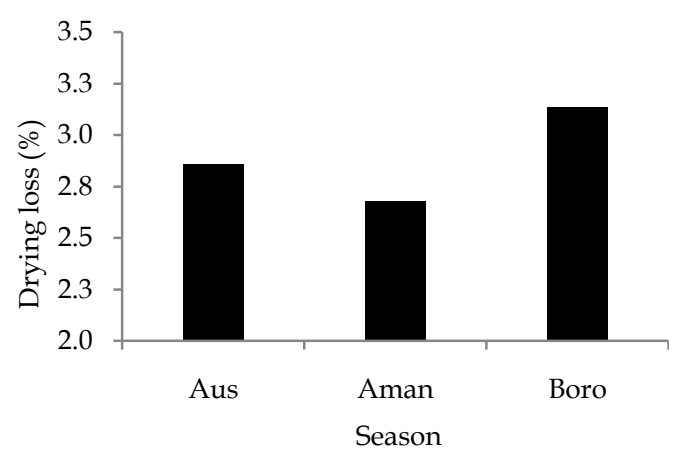

Fig. 1. Drying losses in three distinct seasons. 


\section{Comparative loss estimates on season basis}

Farmers in Gazipur district cultivated different popular rice verities as well as other places of Bangladesh, which were used for postharvest loss assessment from pre-harvest to drying. Pre-harvest, cutting, field stacking, transportation, threshing, cleaning and drying losses were the parts of total losses. Among the different moods of losses, cutting loss only varied significantly with the seasons, whereas in Aus season, it was significantly higher cutting losses $(2.13 \%)$. The total estimated losses were varied 10.42, 10.04 and $10.28 \%$ in Aus, Aman and Boro seasons, respectively (Table 7). Among the three seasons, losses in Aman season (10.04\%) were comparatively lower due to dry weather condition. In contrary, the highest loss was 10.42 in Aus season due to rainy season. The highest losses were found in threshing method (3.09 to $3.23 \%$ ) followed by drying (2.86 to $3.14 \%$ ) and lowest in pre-harvest losses (0.27 to $0.64 \%)$. NAPHIRE (1997) stated that harvest loss in the traditional cutting method (sickle) at optimum maturity stage for different rice varieties ranged from $6 \%$ to $17 \%$, which increased substantially with the delay of harvesting. Calverley (1994) also observed that average loss in harvest, threshing, drying, storage and milling was $13.56 \%$ under eleven FAO projects implemented in several countries of Central and South-Eastern Asia. In another study in China, it was also observed that total average losses of the six operations of threshing, drying and cleaning, storage, transport and milling amounted to $14.81 \%$ of total production (FAO, 2004).

\section{CONCLUSION}

The total postharvest losses from harvesting to drying were observed $10 \%$ in Gazipur district. Mechanical intervention increased the threshing losses whereas it decreased in transportation and winnowing losses. Quantitative relationship between machinery and traditional practice requires further investigation with more representative areas.

Table 7. Season wise rice postharvest losses as affected by different modes and methods of operation.

\begin{tabular}{|c|c|c|c|c|c|c|c|c|c|c|c|c|}
\hline \multirow{2}{*}{ Season } & \multirow{2}{*}{ PHL } & \multirow{2}{*}{ CL } & \multirow{2}{*}{ FSL } & \multirow{2}{*}{ TL } & \multicolumn{3}{|c|}{ Threshing } & \multicolumn{3}{|c|}{ Cleaning } & \multirow{2}{*}{ Drying } & \multirow{2}{*}{ Total } \\
\hline & & & & & SL & USL & Total & SL & Chaff & Total & & \\
\hline Aus & 0.64 & 2.13 & 0.69 & 0.57 & 0.97 & 2.14 & 3.09 & 0.21 & 0.26 & 0.47 & 2.86 & 10.42 \\
\hline Aman & 0.27 & 1.94 & 0.97 & 0.48 & 1.29 & 1.95 & 3.23 & 0.22 & 0.27 & 0.48 & 2.68 & 10.04 \\
\hline Boro & 0.37 & 1.89 & 0.83 & 0.53 & 1.23 & 1.94 & 3.16 & 0.18 & 0.22 & 0.39 & 3.14 & 10.28 \\
\hline $\mathrm{LSD}_{0.05}$ & NS & 0.115 & NS & NS & NS & NS & NS & NS & NS & NS & NS & NS \\
\hline CV (\%) & 16.88 & 1.35 & 8.8 & 5.46 & 6.84 & 5 & 0.90 & 14.29 & 10.85 & 11.23 & 4.72 & 2.12 \\
\hline
\end{tabular}

PHL=Pre-harvest loss, $C L=$ Cutting/harvested loss, FSL=Field stacking loss, TL=Transportation loss, $\mathrm{SL}=$ Scattered loss, USL=Un-separated loss

\section{REFERENCES}

Afsar, A K M Nurul, M A Baqui, Mahfuzur Rahman and M A Rouf. 2001. Grades, standards and inspection procedures of price in Bangladesh. A project completion report submitted to Food Management and Research Support Project, Ministry of Food, GOB, and IFPRI, Bangladesh. http://pdf.usaid.gov/pdf_docs/PNACN994.pdf.
Bala, B K, M A Haque, S Majumdar and M A Hossain. 2010. Postharvest loss and technical efficiency of rice, wheat and maize production system: Assessment and measures for strengthening food security. CF \# 6/08, NFPCSP, Department of Farm Power and Machinery, Bangladesh Agricultural University, Mymensingh, Bangladesh. 
Brolley, M. 2015. Rice security is food security for much of the world. Rice Today, ISSN 1655-5422. JanMar 2015, Vol. 14, No. 1. International Rice Research Institute (IRRI), DAPO Box 7777, Metro Manila, Philippines. PP. 30-32.

BRRI (Bangladesh Rice Research Institute). 2013. http:/ / www.knowledgebank-brri.org / riceinban.php. Accessed on 2 Jan 2013.

BRRI (Bangladesh Rice Research Institute). 2014. Annual Report 2013-14. Bangladesh Rice Research Institute, Gazipur 1701, Bangladesh.

BRRI (Bangladesh Rice Research Institute). 2009. Extension of agricultural machinery at union level. A paper presented by the Farm Machinery and Postharvest Technology Division of BRRI in The Institution of Engineers, Bangladesh, 51 Convention, 2009.

BRRI/FAO. 1986. Study on farm and village level postharvest rice loss assessment in Bangladesh. Field Documentation No. 8. BRRI, Gazipur, Bangladesh.

Calverley, D J B. 1994. Programme for the prevention of food losses: A study of eleven projects in Asia concerned with rice. Final Report, FAO.

FAO (Food and Organization). 2004. Post-harvest losses: Discovering the full story. FAO Corporate Document, available/ / www.fao.org/DOCREP/004/AC301E / AC301e04.

Gomez, K A and A A Gomez. 1984. Statistical procedures for agricultural research (2 ed.), John wiley and sons, NewYork.

Greeley, M. 1981. Farm level rice processing in Bangladesh Food losses, Technical change and implications for future research. Proceeding of the 4th annual workshop on grain postharvest technology held in Philippines 20-22 Jan.
Islam, A K M Saiful, M T Islam, M S Rahman, M A Rahman, M A Kader 2016. Selective mechanization in rice cultivation for enhancing productivity. Publication no. 209. Bangladesh Rice Research Institute, Gazipur, Bangladesh.

Jose, R. Arboleda, Nurul H Choudhury and R A Boxall, 1985. Farm and village level post-harvest rice loss assessment, Bangladesh, Postharvest rice loss assessment manual. AG: GCPP/BGD/017/NET, Field Document1, Bangladesh Rice Research Institute, Ministry of Agriculture, Food and Agriculture Organization of the United Nations, Dhaka, Jul 1985.

Kabir, M S, M U Salam, A Chowdhury, N M F Rahman, K M Iftekharuddaula, M S Rahman, M H Rashid, S S Dipti, A Islam, M A Latif, A K M S Islam, M M Hossain, B Nessa, T H Ansari, M A Ali and J K Biswas. 2016. Rice Vision for Bangladesh: 2050 and Beyond, Bangladesh Rice Journal, Vol. 19(2):1-18, 2015, Bangladesh Rice Research Institute, Gazipur 1701.

MoA (Ministry of Agriculture). 2013. http://www.moa.gov.bd/. Accessed on 2 Oct 2013.

NAPHIRE. 1997. Technical Guide on Grain Postharvest Operation. National Postharvest Institute for Research and Extension (NAPHIRE).Munoz, Nueva Ecija, Philippines.

Statistix 10 software 2013. An analytical software of Statistix 10, Analytical Software Pub Date: 1 Jan 2013. 